\title{
Analysis of Consumer Assessment in Small and Medium Enterprises "Raja Abon Makmur Lestari" on Shredded Products and Mix Marketing
}

\author{
Yulia $^{1}$, Novyandra Ilham Bahtera ${ }^{1}$, Rati Purwasih ${ }^{1}$ \\ *Corresponding Email: yuliaubb@gmail.com \\ ${ }^{1}$ Agribusiness Department, Bangka Belitung University, Indonesia \\ Received: December 29, 2020 \\ Revised: January 5, 2021 \\ Accepted: January 8, 2021
}

\section{Abstract}

Raja Abon Makmur Lestari's business has good potential, resulting in considerable business competition. One of the businesses that produce shredded is Small and Medium Enterprises (UKM) Raja Abon Makmur Lestari. This business must apply a consumer-oriented marketing concept. The application of this concept is to determine the marketing mix consisting of product, price, promotion, and place. The purpose of this study was to analyze consumer assessments of the various attributes of shredded products and evaluate the results of the shredded product marketing mix strategy. The method used in this research is descriptive analysis, with the 4P marketing mix approach. The marketing mix strategy evaluation design involves internal parties, namely business owners, and external parties, namely consumers. The results of the discussion show that consumer assessment of products has guaranteed quality, consumer ratings of prices are in accordance with quality, consumer assessments of shredded product distribution are easy to obtain and consumer assessments of promotion by word of mouth are very efficient and easy to get information on social media. The evaluation results of the marketing mix for shredded products are in the range of 101-125. Based on this total value, it can be concluded that all the variables of the marketing mix carried out by the king of shredded and prosperous sustainable have been effective.

Keywords: Shredded, Consumer Assessment, Mix Marketing, Strategy Evaluation

\section{Introduction}

Indonesia is a country with a large population. The Province of Bangka Belitung Islands, especially Pangkalpinang City, is a densely populated area, compared to other areas, such as other districts. According to Department of Cooperation, Trade, Industry and Medium Small Business, the city of Pangkalpinang is entering the era of globalization, the faster information is obtained, technology is higher and community activities are also increasing. This condition causes a shift in people's behavior, including in terms of food consumption. People tend to choose foods that are more practical but do not reduce the nutritional content of these foods, for example, various types of shredded beef, chicken, eggs, jackfruit, banana blossoms, pineapples, and so on (Yulia et al, 2019).

According to (Yulia et al, 2020) seeing a very good market potential for processed products, especially processed products from animal and vegetable raw materials, many companies have emerged that produce these processed products. This condition creates increasingly fierce business competition, therefore companies must apply the marketing concept. The marketing concept here is consumer-oriented because it aims to provide satisfaction with consumer wants or needs, including in determining marketing strategies to maintain products in the market (Asmarantaka, 2014). One of these marketing concepts is the preparation of a

Copyright @ 2021, Journal of Asian Multicultural Research for Economy and Management Study, Under the license CC BY-SA 4.0 
marketing mix, which is the main activity in determining a marketing strategy (Budiwati, 2012; Yulia et al., 2019; Yulia et al., 2020). According to Subagyo (2010) said that the marketing mix will combine four variables, namely product, price, promotion, distribution.

Raja Abon Makmur Lestari's business is a business that produces various kinds of processed products from vegetable and animal raw materials. The preparation of the right marketing mix must pay attention to consumer ratings for each product, the consumer's assessment can be seen from consumer attitudes towards each of these shredded products (Luan \& Sudhir, 2010; Leonidou et al., 2013; Dost et al., 2019). According to Yulia et al., 2019) seeing from the large influence of consumers on the marketing mix that allows the creation of the right marketing strategy for shredded products, the owner must pay attention to consumer wants or needs so that consumer satisfaction is achieved with the shredded products offered.

\section{Methods}

This research was conducted at one of the SMEs (Small and Medium Enterprises) in the city of Pangkalpinang, which is one of the SMEs that has the potential to market Abon products. Raja Abon Makmur Lestari produces premium quality shredded floss. The sampling that was carried out in this study was divided into two, namely, internal respondents and external respondents. Determination of internal respondents using a purposive sampling method. Meanwhile, the determination of external respondents was carried out using a convenience sampling method. The number of samples of consumer respondents is 30 samples and is considered capable of representing consumer opinions. The selected respondents consisted of consumers who bought various types of processed shredded products.

The method of processing and data analysis used in this research is descriptive qualitative analysis. Descriptive analysis is used to determine and evaluate the marketing activities of shredded products that have been implemented by the Raja shredded and prosperous sustainable through the 4P marketing mix approach (product, price, promotion, distribution). In addition, descriptive analysis is also used to evaluate the priority of the resulting marketing mix strategy. Marketing mix strategy evaluation is carried out through consumer perceptions/assessments of the marketing mix attributes of shredded products using a Likert scale (Budiwati, 2012). The Likert scale used in this study is a balanced scale. By using a balanced scale it is expected to produce objective data.

According to Selang (2013) shows that the level of consumer perception is measured using five scales, namely strongly agree, agree, quite agree, disagree, and strongly disagree. Furthermore, the data obtained from the results of consumer perceptions were calculated using descriptive tabulations. The data is grouped according to consumer answers and percentage based on the number of consumer respondents. After that, the consumers' answers are converted to a scale of values related to their perceived weight. Consumers' perceptions and perceptual weights are listed in Table 1.

Table 1 Consumer Perception and Perception Weight

\begin{tabular}{|l|c|}
\hline Consumer Perception & Perception Weight \\
\hline Strongly Agree & 5 \\
\hline Agree & 4 \\
\hline Somehow Agree & 3 \\
\hline Disagree & 2 \\
\hline Strongly Disagree & 1 \\
\hline
\end{tabular}


Then the total value is interpreted based on the range of the effectiveness scale. According to Simamora (2002), the range of effectiveness scales is used to provide an interpretation of consumer assessments. The formula for getting the effectiveness scale range is as follows:

$\mathrm{RS}=\frac{m-n}{B}$

Where $\mathrm{m}$ is the Maximum score, $\mathrm{n}$ is the Minimum score, $\mathrm{B}$ is the number of classes formed, and RS is Scale Range.

In determining the range of the consumer rating effectiveness scale from $\mathrm{m}=$ the maximum score of 150 obtained from the multiplication of respondents who answered strongly agree with the total number of respondents, while $n=$ the minimum score of 30 was obtained from the multiplication of respondents who answered strongly disagree with the total number of respondents, and $\mathrm{B}=$ the number of classes formed is 5 .

\section{Results and Discussion}

\section{Analysis of Consumer Assessment of Marketing Mix}

According to Hurriyati (2005), consumer behavior is the basis for the formulation of a marketing strategy. Consumer assessment in the form of reactions to marketing strategies can determine the success or failure of an organization/business in an effort to make consumers willing to buy the goods offered (Supranto and Limakrisna, 2007). In addition, consumers are parties who can judge the success of a business organization in an effort to meet their needs and desires. Therefore, the consumer's assessment of the marketing mix of shredded products focuses on the desires and satisfaction of consumers so that there is an input from consumers on the marketing strategy that should be carried out by the management of the king of shredded and prosperous sustainable (Yulia et al., 2019). Consumer assessment was carried out by conducting interviews and filling out questionnaires to 30 consumers who had various characteristics. Consumer characteristics can be seen from gender, age, occupation, domicile, and income per month. The sampling method from the consumer was carried out by convenience sampling method. The results of the characteristics of the shredded respondents can be seen in Table 2 .

Table 2 Characteristics of shredded respondents in the king of shredded and prosperous sustainable

\begin{tabular}{|c|l|l|l|l|}
\hline Respondent Characteristic & Criteria & Amount & Percentage (\%) & Total (\%) \\
\hline \multirow{3}{*}{ Domisili } & Pangkalpinang & 27 & 90 & 100 \\
\cline { 2 - 5 } & $\begin{array}{l}\text { Outside } \\
\text { Pangkalpinang }\end{array}$ & 3 & 10 & \\
\hline \multirow{2}{*}{ Agx } & Male & 11 & 36.33 & 100 \\
\cline { 2 - 5 } & Female & 19 & 63.67 & 100 \\
\hline \multirow{3}{*}{ Employment } & $\leq 20$ & 12 & 40 & \\
\cline { 2 - 6 } & $21-25$ & 6 & 20 & \\
\cline { 2 - 6 } & $>25$ & 12 & 40 & \\
\hline & Student & 14 & 46.67 & \\
\cline { 2 - 6 } & Civil Servant & 3 & 10 & \\
\cline { 2 - 6 } & $\begin{array}{l}\text { Private } \\
\text { employees }\end{array}$ & 4 & 13.33 & \\
\cline { 2 - 5 } & Entrepreneur & 6 & 20 & \\
\cline { 2 - 5 } & Other & 3 & 10 & \\
\hline
\end{tabular}




\begin{tabular}{|l|l|l|l|l|}
\hline \multirow{4}{*}{ Income/Month } & $\begin{array}{l}<\mathrm{Rp} . \\
1.000 .000\end{array}$ & 8 & 26.67 & 100 \\
\cline { 2 - 5 } & $\begin{array}{l}\text { Rp. } 1.000 .000- \\
\text { Rp. 2.499.999 }\end{array}$ & 13 & 43.33 & \\
\cline { 2 - 5 } & $\begin{array}{l}\text { Rp. 2.500.000- } \\
\text { Rp 4.999.999 }\end{array}$ & 5 & 16.67 & \\
\cline { 2 - 6 } & $>5.000 .000$ & 4 & 13.33 & \\
\hline
\end{tabular}

Based on Table 2, it can be seen that the majority of consumers who buy shredded floss at the Raja Shredded Makmur Lestari are people who live in the Pangkalpinang area with a percentage of 90 percent and people outside Pangkalpinang by 10 percent, respondents from outside Pangkalpinang come from Jakarta, Bandung, and Bali. Based on gender, the majority of respondents are female consumers with a percentage of 63.33 percent and men at 36.67 percent, this shows that women tend to have an interest and love for shredded products, but with the diversification of shredded products it does not rule out men also starting to consume shredded. Furthermore, 40 percent of respondents were less than the same as twenty years old, 20 percent of the respondents were 21-25 years old, and 40 percent of the respondents were more than twenty-five years old. Then seen from the job, 46.67 percent of respondents were students, the rest were civil servants by 10 percent, private and self-employed employees respectively 13.33 percent and 20 percent and outside the profession was 10 percent. In the income distribution, most of the respondents are classified as having income between Rp. 1,000,000 to Rp. 2,499,999.

\section{Consumer Assessment of Mixed Product}

Consumer assessment of the product is important to do to see to what extent the needs and desires of consumers for the product can be fulfilled by the Raja of the prosperous and sustainable Shredded. The assessment of the product is related to the quality, taste, and form of the processed products offered. The results of the assessment can be seen in Table 3 .

Table 3. Consumer assessment of the product mix

\begin{tabular}{|c|c|c|c|c|}
\hline $\begin{array}{c}\text { Consumer } \\
\text { Assessment }\end{array}$ & Criteria & Amount & Percentage & Total \\
\hline \multirow{5}{*}{$\begin{array}{l}\text { Quality } \\
\text { guaranteed }\end{array}$} & Strongly Agree & 8 & 26.67 & \multirow{5}{*}{123} \\
\hline & Agree & 17 & 56.67 & \\
\hline & Somehow Agree & 5 & 16.67 & \\
\hline & Disagree & 0 & 0.00 & \\
\hline & Strongly Disagree & 0 & 0.00 & \\
\hline \multirow{5}{*}{$\begin{array}{l}\text { Flavors according } \\
\text { to your wishes }\end{array}$} & Strongly Agree & 4 & 13.33 & \multirow{5}{*}{111} \\
\hline & Agree & 15 & 50 & \\
\hline & Somehow Agree & 9 & 30 & \\
\hline & Disagree & 2 & 6.67 & \\
\hline & Strongly Disagree & 0 & 0.00 & \\
\hline \multirow{5}{*}{$\begin{array}{c}\text { Available in } \\
\text { various forms }\end{array}$} & Strongly Agree & 5 & 16.67 & \multirow{5}{*}{116} \\
\hline & Agree & 18 & 60 & \\
\hline & Somehow Agree & 5 & 16.67 & \\
\hline & Disagree & 2 & 6.67 & \\
\hline & Strongly Disagree & 0 & 0.00 & \\
\hline
\end{tabular}


Based on the table above, it can be seen that as many as 56.57 percent of consumers agree that the Raja Shredded and Prosperous products offered have guaranteed quality. Assessment of product quality is seen from the freshness of the distinctive aroma and taste of coffee. Consumers consider the shredded product offered to have a fragrant and delicious shredded aroma, this is because the shredded offered is a fresh shredded product that is just cooked / dried when the consumer buys it. In addition, shredded products have a good taste, because they are produced from selected raw materials. Consumers who judge the quality of the product as guaranteed are generally loyal consumers of Raja shredded and prosperous sustainably who are classified as lovers of fast food with nutritional value. Meanwhile, 16.67 percent stated that they quite agreed with the guaranteed quality of shredded products. The total score for guaranteed quality is 123 , which means that the strategy is effective against consumer judgment.

Furthermore, related to the variation of taste, as much as 13.33 percent of consumers strongly agree and 50 percent of respondents think that they agree that the variations in the types of floss offered are in accordance with their wishes, 30 percent say they quite agree and 16.67 percent say they disagree. So that the total value obtained is 111 , which means that the strategy is effective in consumer assessment. The next assessment regarding the availability of products in various forms includes 16.67 percent of respondents strongly agree, 60 percent agree, 16.67 percent quite agree and the remaining 6.67 percent disagree. It was then obtained a total value of 116 , which means that the strategy is effective in consumer assessment.

Table 4. Reasons for purchasing shredded products at Raja Abon Makmur Lestari

\begin{tabular}{|c|c|c|l|l|}
\hline \multirow{2}{*}{ Description } & Criteria & \multirow{2}{*}{ Amount } & Percentage (\%) & \multirow{2}{*}{ Total (\%) } \\
\hline \multirow{2}{*}{$\begin{array}{c}\text { Reasons for } \\
\text { Purchasing } \\
\text { Shredded }\end{array}$} & Shredded Quality & 12 & 40 & \multirow{3}{*}{100} \\
\cline { 2 - 5 } & Affordable Price & 10 & 33.33 & \\
\cline { 2 - 5 } & Product Availability & 5 & 16.67 & \\
\cline { 2 - 4 } & Interesting Promotion & 3 & 10 & \\
\hline
\end{tabular}

Judging from table 4, it is known that most of the main reasons for purchasing shredded products are because of the quality of shredded products by 40 percent. Consumers feel the shredded quality offered is indeed premium quality. Apart from the quality of the shredded, the next reason is the affordable price of the product, which is 33.33 percent. According to consumers, when compared to other similar products, the price of the shredded product offered by Raja Abon and prosperous sustainable is more affordable. Then, other reasons are the availability of products by 16.67 percent and attractive promotions of 10 percent.

Table 5. The purpose of purchasing shredded floss in Raja Abon prosperous sustainably

\begin{tabular}{|c|l|c|c|c|}
\hline \multirow{2}{*}{ Description } & \multicolumn{1}{|c|}{ Criteria } & Amount & Percentage (\%) & Total (\%) \\
\hline \multirow{2}{*}{$\begin{array}{c}\text { The purpose of } \\
\text { purchasing } \\
\text { shredded }\end{array}$} & Habits / hobbies & 14 & 46.67 & \\
\cline { 2 - 4 } & Try & 11 & 36.67 & \multirow{2}{*}{100} \\
\cline { 2 - 4 } & $\begin{array}{l}\text { Re-sell } \\
\text { Meet the needs of the } \\
\text { shop/tavern }\end{array}$ & 5 & 16.67 & \\
\hline
\end{tabular}

As many as 46.67 percent of consumers stated that the purpose of purchasing shredded floss at Raja Abon is sustainable because of their habits or hobbies, consumers with this aim are

Copyright $\odot$ 2021, Journal of Asian Multicultural Research for Economy and Management Study, 
food lovers who have become loyal customers of Raja Bon Makmur Lestari. The next goal is to try products of 36.67 percent, most of them are new consumers who want to know the flavors of the various shredded products offered by the king of shredded and prosperous lifestyles. Not only that, 16.67 percent of respondents stated that the purpose of purchasing shredded products was to be resold.

\section{Consumer Assessment of Price Mix}

Affordability and price compatibility with taste and quality are aspects of the assessment of the price mix. Following is the consumer's assessment of the price mix can be seen in Table 6.

Table 6. Consumer Assessment of Price Mix

\begin{tabular}{|c|c|c|c|c|}
\hline $\begin{array}{c}\text { Consumer } \\
\text { Assessment }\end{array}$ & Criteria & Amount & Percentage & $\begin{array}{l}\text { Total } \\
\text { Value }\end{array}$ \\
\hline \multirow{5}{*}{ Affordable Prices } & Strongly Agree & 6 & 20 & \multirow{5}{*}{119} \\
\hline & Agree & 17 & 56.67 & \\
\hline & Somehow Agree & 7 & 23.33 & \\
\hline & Disagree & 0 & 0.00 & \\
\hline & Strongly Disagree & 0 & 0.00 & \\
\hline \multirow{5}{*}{$\begin{array}{l}\text { Prices according } \\
\text { to taste }\end{array}$} & Strongly Agree & 5 & 16.67 & \multirow{5}{*}{118} \\
\hline & Agree & 18 & 60 & \\
\hline & Somehow Agree & 7 & 23.33 & \\
\hline & Disagree & 0 & 0.00 & \\
\hline & Strongly Disagree & 0 & 0.00 & \\
\hline \multirow{5}{*}{$\begin{array}{l}\text { Price according } \\
\text { to quality }\end{array}$} & Strongly Agree & 10 & 33.33 & \multirow{5}{*}{125} \\
\hline & Agree & 15 & 50 & \\
\hline & Somehow Agree & 5 & 16.67 & \\
\hline & Disagree & 0 & 0.00 & \\
\hline & Strongly Disagree & 0 & 0.00 & \\
\hline
\end{tabular}

Based on the consumer's assessment, 20 percent stated strongly that the shredded price offered was affordable, and 56.57 percent agreed. Buyers with high income tend not to mind the price, especially if the consumer is a shredded product lover who really cares about the quality of shredded. For example shredded beef, chicken and shredded vegetables such as banana flower. Furthermore, 23.33 percent stated that they quite agreed with affordable prices. So that the total value obtained is 119 , which means that the strategy has been effective.

The next assessment regarding the suitability of price with taste, as many as 16.67 percent stated that they strongly agreed that the price set was according to taste. Then as many as 60 percent of respondents agreed, and 23.33 percent said they quite agreed. So that the total value obtained is 118 , which means that the strategy has been effective.

The suitability of price with quality is the final assessment. As many as 50 percent of respondents agreed that the price offered was in accordance with the quality. Then as many as 33.33 percent stated that they strongly agreed. Furthermore, 16.67 percent stated that they quite agreed. So that the total value obtained is 125 , which means that the strategy has been effective. 


\section{Consumer Assessment of the Distribution Mix}

The distribution mix in the shredded and prosperous king business is the place where the shredded product is located, because the shredded product is a place for consumers to get products and services directly. The aspects of the distribution mix assessed by consumers in this study are the location where the shredded production is, the ease of obtaining the product and the availability of the product. As many as 36.67 percent of consumers considered that they agreed with the strategic shredded production location, 26.67 percent of consumers considered the location of the shredded shredded to be very strategic, 26.67 percent of consumers considered the location where the production was quite strategic and the remaining 10 percent said it was not strategic. Based on this assessment, a total value of 114 was obtained. This value shows that the distribution mix in the form of production locations is effectively accessible to consumers. Consumer assessment of the distribution mix can be seen in Table 7.

Table 7. Consumer Assessment of Distribution Mix

\begin{tabular}{|c|c|c|c|c|}
\hline Consumer Assessment & Criteria & Amount & Percentage & Total \\
\hline \multirow{5}{*}{ Strategic location } & Strongly Agree & 8 & 26.67 & \multirow{5}{*}{114} \\
\hline & Agree & 11 & 36.67 & \\
\hline & Somehow Agree & 8 & 26.67 & \\
\hline & Disagree & 3 & 10 & \\
\hline & Strongly Disagree & 0 & 0.00 & \\
\hline \multirow{5}{*}{$\begin{array}{l}\text { Shredded products are } \\
\text { easy to obtain }\end{array}$} & Strongly Agree & 6 & 20 & \multirow{5}{*}{116} \\
\hline & Agree & 16 & 53.33 & \\
\hline & Somehow Agree & 6 & 20 & \\
\hline & Disagree & 2 & 6.67 & \\
\hline & Strongly Disagree & 0 & 0.00 & \\
\hline \multirow{5}{*}{$\begin{array}{c}\text { Products are always } \\
\text { available }\end{array}$} & Strongly Agree & 5 & 16.67 & \multirow{5}{*}{111} \\
\hline & Agree & 13 & 43.33 & \\
\hline & Somehow Agree & 10 & 33.33 & \\
\hline & Disagree & 2 & 6.67 & \\
\hline & Strongly Disagree & 0 & 0.00 & \\
\hline
\end{tabular}

\section{Consumer Assessment of Promotion Mix}

The last assessment conducted was an assessment related to the promotion mix. The things that are assessed are the promotional activities that have been carried out by the king of shredded and prosperous sustainable. As many as 50 percent of respondents agreed with the bazaar and seminar attended by the king of shredded and prosperous sustainable educating. With a total value obtained of 110 , which means that the strategy is effective in consumer assessment. Furthermore, in the assessment of respondents related to social media, as many as 50 percent of respondents agreed that social media made it easier to get information. With a total value obtained of 115, which means that the strategy is effective in consumer assessment. The last assessment was related to promotion through bazaar activities, as many as 43.37 percent of respondents considered that promotion through word of mouth or bazaar was efficient. The results of consumer assessment of the promotional mix can be seen in Table 8.

Table 8 Consumer Assessment of Promotion Mix

\begin{tabular}{|l|l|l|l|l|}
\hline Consumer Assessment & Criteria & Amount & Percentage & Total \\
\hline
\end{tabular}




\begin{tabular}{|c|l|c|l|l|}
\hline \multirow{4}{*}{$\begin{array}{c}\text { The bazaar is } \\
\text { interesting and } \\
\text { educational }\end{array}$} & Strongly Agree & 4 & 13.33 & \\
\cline { 2 - 5 } & Agree & 15 & 50 & \\
\cline { 2 - 5 } & Somehow Agree & 8 & 26.67 & 110 \\
\cline { 2 - 5 } & Disagree & 3 & 10 & \\
\cline { 2 - 5 } & Strongly Disagree & 0 & 0.00 & \\
\hline \multirow{3}{*}{\begin{tabular}{c} 
Social media makes it $\begin{array}{c}\text { easier to get } \\
\text { information }\end{array}$ \\
\cline { 2 - 5 }
\end{tabular}} & Strongly Agree & 6 & 20 & \\
\cline { 2 - 5 } & Agree & 15 & 50 & \\
\hline \multirow{3}{*}{$\begin{array}{c}\text { Promotion by word of } \\
\text { mouth is efficient }\end{array}$} & Somehow Agree & 7 & 23.33 & 115 \\
\cline { 2 - 5 } & Disagree & 2 & 6.67 & \\
\cline { 2 - 5 } & Strongly Disagree & 0 & 0.00 & \\
\cline { 2 - 5 } & Atrongly Agree & 8 & 26.67 & \\
\cline { 2 - 5 } & Somehow Agree & 6 & 20 & 115 \\
\cline { 2 - 5 } & Disagree & 2 & 6.67 & \\
\cline { 2 - 5 } & Strongly Disagree & 1 & 3.33 & \\
\hline
\end{tabular}

\section{Result of Evaluation of Shredded Product Marketing Mix Strategy}

Based on the consumer's assessment of the marketing strategy applied by the king of shredded and prosperous lifestyles, the results of the evaluation of the shredded marketing mix strategy are obtained. The results of the evaluation were obtained from the multiplication tabulation results between the criteria weights and the number of respondents. With the scale range determined based on the Likert scale of 24 , so that a very effective interval is obtained between 126-150, effective in the 101-125 range, quite effective in the 76-100 range, 51-75 ineffective, and very ineffective 26- 50.

The total value obtained in the evaluation of the marketing mix for shredded products is in the range 101-125. Based on the total value, it can be concluded that all the variables of the marketing mix by the king of shredded and prosperous sustainable have been effective. That way the king of shredded and prosperous needs to maintain the marketing mix that has been determined to maintain customer satisfaction, and also make improvements so that all the marketing mix variables become very effective.

Consumers' assessment of consumer perceptions of the attributes of the marketing mix can be an input in the formation and determination of alternative marketing strategies that are appropriate for the king of shredded and prosperous sustainable in the future. The results of the evaluation of the overall marketing strategy can be seen in Table 9.

Table 9. Evaluation Results of Marketing Mix in Raja Abon prosperous sustainably

\begin{tabular}{|c|c|c|c|}
\hline No & $\begin{array}{r}\text { Marketing mix strategy } \\
\end{array}$ & Total Score & Description \\
\hline \multicolumn{4}{|c|}{ Product Mix Strategy } \\
\hline \multirow{3}{*}{1} & Quality guaranteed & 123 & Effective \\
\hline & Variety of flavors & 111 & Effective \\
\hline & Various Forms of Processed & 116 & Effective \\
\hline \multicolumn{4}{|c|}{ Price Mix Strategy } \\
\hline \multirow{3}{*}{2} & Affordable Price & 119 & Effective \\
\hline & Appropriateness of price and taste & 118 & Effective \\
\hline & Price and quality suitability & 125 & Effective \\
\hline \multicolumn{4}{|c|}{ Distribution Mix Strategy } \\
\hline 3 & Strategic business location & 114 & Effective \\
\hline
\end{tabular}

Copyright (C) 2021, Journal of Asian Multicultural Research for Economy and Management Study, Under the license CC BY-SA 4.0 


\begin{tabular}{|l|l|l|l|}
\hline \multirow{2}{*}{} & Ease of obtaining & 116 & Effective \\
\cline { 2 - 4 } & products through the shop & 111 & Effective \\
\hline \multicolumn{2}{|l|}{ Promotion Mix Strategy Inventory } & 110 & Effective \\
\hline \multirow{3}{*}{4} & Interesting and Educational bazaar & 115 & Effective \\
\cline { 2 - 4 } & Medsos makes it easier to get information & 115 & Effective \\
\cline { 2 - 4 } & Word of mouth is efficient &
\end{tabular}

\section{Conclusion}

Raja Abon makmur lestari has carried out marketing activities that can be analyzed through the marketing mix (4P), namely product, price, distribution and promotion. The product marketing mix strategy applied by the owner has changed with the routine evaluation by the business owner of the product. Initially, only one type of product was sold, namely kemplang crackers, but now the owner has sold various types of shredded products in various forms, namely shredded processed raw materials for vegetable products and shredded processed animal products. The price mix strategy adopted by the owners also changes in line with financial conditions and business developments. Various promotional activities were carried out by the owner to introduce shredded products ranging from bazaars, exhibitions, social media, endorsements and mass media which are still being carried out today. The distribution of shredded products is increasingly widespread with the existence of Small and Medium Enterprises (UKM) Mart outlets (Transmart Pangkalpinang) and Houses for production that accommodate the marketing activities of shredded products. Based on the consumer assessment analysis, it is concluded that all marketing mix variables that have been carried out by the owner of the king of shredded and prosperous sustainable between 110-125.

\section{References}

Asmarantaka, RW. (2014). Pemasaran Agribisnis (Agrimarketing). Bogor (ID). IPB Press

Budiwati, H. (2012). Implementasi marketing mix dan pengaruhnya terhadap keputusan pembelian konsumen pada produk unggulan keripik pisang Agung di Kabupaten Lumajang. WIGA: Jurnal Penelitian Ilmu Ekonomi, 2(2), 36622.

Dost, F., Phieler, U., Haenlein, M., \& Libai, B. (2019). Seeding as part of the marketing mix: word-of-mouth program interactions for fast-moving consumer goods. Journal of Marketing, 83(2), 62-81.

Hurriyati, R. (2005). Bauran pemasaran \& loyalitas konsumen. Bandung: Alfabeta.

Leonidou, C. N., Katsikeas, C. S., \& Morgan, N. A. (2013). "Greening” the marketing mix: Do firms do it and does it pay off?. Journal of the Academy of Marketing Science, 41(2), 151-170.

Luan, Y. J., \& Sudhir, K. (2010). Forecasting marketing-mix responsiveness for new products. Journal of Marketing Research, 47(3), 444-457.

Selang, C. A. (2013). Bauran pemasaran (marketing mix) pengaruhnya terhadap loyalitas konsumen pada fresh mart Bahu Mall Manado. Jurnal EMBA: Jurnal Riset Ekonomi, Manajemen, Bisnis dan Akuntansi, 1(3).

Simamora, B. (2002). Panduan riset perilaku konsumen. Gramedia Pustaka Utama.

Subagyo, A. (2010). Marketing in Business. Penerbit Mitra Wacana Media.

Supranto, J., \& Limakrisna, N. (2007). Perilaku konsumen dan strategi pemasaran untuk memenangkan persaingan bisnis. Jakarta: Mitra Wacana Media. 
Yulia, A. K. P., \& Purwasih, R. (2019). Pendampingan Usaha Produksi Ukm Raja Abon Makmur Lestari Berbasis Marketing Strategy. In Prosiding Seminar Hukum dan Publikasi Nasional (Serumpun) (Vol. 1, No. 1, pp. 397-406).

Yulia, Y., Bahtera, N. I., \& Evahelda, E. (2019). A SWOT Analysis on the Implementation of the Marketing Strategy: A Case Study in the Raja Abon Makmur Lestari, Pangkalpinang City, Indonesia. International Journal of Business and Economy, 1(2), 26-32.

Yulia, Y., Bahtera, N. I., Evahelda, E., Hayati, L., \& Bahtera, N. T. (2020). Business Development Strategy Using Business Model Canvas Approach. Jurnal Muara Ilmu Ekonomi dan Bisnis, 4(1), 106-115. 